\title{
Differences of Lower Urinary Tract Symptoms Degree in Benign Prostatic Hyperplasia Patients With and Without Diabetes Mellitus
}

\section{Jeannis Clarissa ${ }^{1}$, Syah Mirsya Warli², Dhirajaya Dharma Kadar ${ }^{2}$,and Nurfida Khairina Arrasyid ${ }^{3}$}

${ }^{1}$ Faculty of Medicine, Universitas Sumatera Utara, Medan, North Sumatera, Indonesia

${ }^{2}$ Department of Urology, Faculty of Medicine, Universitas Sumatera Utara, Medan, North Sumatera, Indonesia

${ }^{3}$ Department of Parasitology, Faculty of Medicine, Universitas Sumatera Utara, Medan, North Sumatera, Indonesia

\begin{abstract}
.
Background. Benign Prostatic Hyperplasia (BPH) is a benign tumor that most often occurs in men. Many risk factors could cause BPH, one of which is diabetes mellitus (DM). Diabetes mellitus (DM) is a metabolic disease, characterized by hyperglycemia. Method. This study was conducted at the Urology Polyclinic of the Universitas Sumatera Utara Hospital from August to September 2019. A total of 102 patients diagnosed with BPH were registered by cross-sectional study approach. Detailed medical history and physical examination were performed for all patients to diagnose BPH. While the diagnosis of DM was according to patient history or diabetic-medicine use. International Prostate Symptom Score (IPSS) were completed by all patients to obtain a LUTS degree.

Result. From a total of 102 patients diagnosed with BPH there were 97 patients were selected. The mean age of patients was $70.43 \pm 7.52$ year (range 50-88 year) and the total IPSS score was $17.55 \pm 6.55$. DM patients were more likely to report severe LUTS and the symptom score evaluated with IPSS was significantly higher than in non non-DM group: $21.69 \pm 5.41$ vs $16.70 \pm 6.41(\mathrm{p}=0.005)$. For the IPSS subscores, the DM group also show higher storage: $8.38 \pm 4.57$ vs $5.88 \pm 3.72(\mathrm{p}=0.02$ ), voiding: $9.69 \pm 2.47$ vs $8.14 \pm 3.21$, $(\mathrm{p}=0.039)$ and post micturition: $3.63 \pm 1.26$ vs $2.69 \pm 1.744$, $(\mathrm{p}=0.045)$ symptoms significantly.
\end{abstract}

Conclusion: Benign Prostatic Hyperplasia patients with DM manifested more severe lower urinary tract symptoms. Storage, voiding, post micturition, and urgency symptoms were also greater.

*Corresponding author at: Faculty of Medicine, Universitas Sumatera Utara, Medan, North Sumatera, Indonesia

E-mail address: jeannisclarissa@gmail.com 
Keywords: BPH, DM, IPSS, LUTS Degree

\begin{abstract}
ABSTRAK.
Latar belakang. Benign Prostatic Hyperplasia (BPH) adalah tumor jinak yang paling sering terjadi pada pria. Banyak faktor risiko yang dapat menyebabkan BPH, salah satunya adalah diabetes mellitus (DM). Diabetes mellitus (DM) adalah penyakit metabolik, ditandai dengan hiperglikemia.
\end{abstract}

Metode. Penelitian ini dilakukan di Poliklinik Urologi Rumah Sakit Universitas Sumatera Utara dari Agustus hingga September 2019. Sebanyak 102 pasien yang didiagnosis dengan BPH terdaftar dengan pendekatan studi potong lintang. Dirinci riwayat medis dan dilakukan pemeriksaan fisik untuk semua pasien untuk mendiagnosis BPH. Sedangkan diagnosis DM sesuai riwayat pasien atau penggunaan obat diabetes. Dilakukan pemeriksaan International Prostate Symptom Score (IPSS) pada semua pasien untuk mendiagnosa LUTS.

Hasil. Dari total 102 pasien yang didiagnosis dengan BPH, ada 97 pasien yang dipilih. Usia pasien adalah 70,43 \pm 7,52 tahun (kisaran 50-88 tahun) dan total skor IPSS adalah 17,55 $\pm 6,55$. Pasien DM lebih melaporkan LUTS berat dan evaluasi skor gejala dengan IPSS secara signifikan lebih tinggi daripada pada kelompok non-DM: 21,69 $\pm 5,41$ vs 16,70 $\pm 6,41$ ( $p=0,005)$. Grup DM juga lebih tinggi secara signifikan pada IPSS skor: 8,38 $\pm 4,57$ vs 5,88 $\pm 3,72(p=0,02)$, berkemih: 9,69 $\pm 2,47$ vs 8,14 $\pm 3,21,(p=0,039)$ dan setelah berkemih: $3.63 \pm 1,26$ vs 2,69 \pm 1.744 , $(p=0,045)$.

Kesimpulan: Pasien BPH dengan DM manifestasi gejala saluran kemih bagian bawah lebih berat. Menahan berkemih, berkemih, setelah berkemih, dan gejala urgensi juga lebih besar.

Kata kunci: BPH, DM, IPSS, derajat LUTS

Received 22 June 2021 | Revised 29 July 2021 | Accepted 30 August 2021

\title{
1 Introduction
}

Benign Prostatic Hyperplasia (BPH) is a histologic diagnosis that refers to the proliferation of smooth muscle and epithelial cells within the prostatic transition zone.[1] It is the most common benign tumor found in men.[2] The incidence of BPH is depended on age. BPH results in compression of the urethra, causing resistance to urine flow known as bladder outlet obstruction (BOO). This resistance can also result in changes in bladder function, such as overactivity of the detrusor muscle or, conversely, reduced contractility of the detrusor muscle that is known as Lower Urinary Tract Symptoms (LUTS).[3]

The International Continence Society has divided LUTS into three categories, voiding, storage, and post micturition. Voiding symptoms correspond to urinary hesitancy, straining, intermittency, weak urinary stream, and dysuria. Storage symptoms correspond to urinary frequency, nocturia, and urgency with or without incontinence. Post micturition symptoms correspond to the sensation of incomplete voiding, and/or post micturition dribbling.[4,5] A guideline to direct those 
symptoms due to prostate enlargement is the complaint scoring system, known as the International Prostate Symptoms Score (IPSS) questionnaire.[6]

$\mathrm{BPH}$ and diabetes have significant overlap in voiding dysfunction symptoms, but evidence also exists that diabetes promotes the disease process of BPH. Disruptions in glucose homeostasis at multiple different levels - from alterations in serum insulin growth factor concentrations to diagnosis of clinical diabetes - are associated with higher likelihoods of prostate enlargement, BPH, and LUTS.[7,8] In the Baltimore Longitudinal Study of Aging, Parsons et al. noted that men with diabetes were more likely to have LUTS three times than men without diabetes.[9] Fasting insulin plasma also is an independent risk factor of prostatic gland volume. Diabetes could double moderate-severe LUTS risk.[10] The objective of this research is to compare the degree of LUTS in benign prostatic hyperplasia patients with and without diabetes mellitus based on the IPSS score.

\section{Method}

This study was conducted at the Urology Polyclinic of the Universitas Sumatera Utara Hospital from August to September 2019. A total of 102 patients diagnosed with Benign Prostatic Hyperplasia were registered by cross-sectional study approach with a total sampling technique. Then 97 patients were selected due to exclusion criteria which were neurologic bladder dysfunction, bladder stones, and urinary tract infection. Among those 97 patients, 81 patients did not have DM and 16 patients had DM.

Detailed medical history and physical examination were performed for all patients to diagnose $\mathrm{BPH}$. While the diagnosis of DM was according to patient history or diabetic-medicine use. International Prostate Symptom Score (IPSS) were completed by all patients to obtain a LUTS degree.

Statistical analysis

Statistical analysis was done by using SPSS 24.0 (SPSS Inc., Chicago, IL, USA). All data are statically described in terms of mean \pm standard deviation (SD) and frequencies. We divided the population into two groups: patients with and without DM group. The total IPSS score, storage score, voiding score, post micturition, and their subscores were compared between the two groups by independent sample t-test with normal-data-distribution assumptions (Kolmogorov-Smirnov, $P>0.05)$. The assumptions that did not meet would be replaced by Levene's test. Differences resulting in a $\mathrm{P}<0.05$ in equal variances assume row were considered statistically significant if Levene's test was above 0.05 and vice versa. 


\section{Results}

In table 1, shows that the mean age of 97 patients was $70.43 \pm 7.52$ (range 50-88) and the total IPSS score was $17.55 \pm 6.55$.

Table 1 Patient Characteristics

\begin{tabular}{lc}
\hline \multicolumn{1}{c}{ Variables } & Mean \pm SD \\
\hline Number of patients & 97 \\
Age (year) & $70.43 \pm 7.521$ \\
Total IPSS & $17.55 \pm 6.55$ \\
& \\
\hline
\end{tabular}

In table 2, DM patients were more likely to report severe LUTS and the symptom score evaluated with IPSS was significantly higher than in non non-DM group: $21.69 \pm 5.41$ vs $16.70 \pm 6.41$ $(\mathrm{p}=0.005)$. For the IPSS subscores, the DM group also show higher storage: $8.38 \pm 4.57$ vs 5.88 $\pm 3.72(\mathrm{p}=0.02)$, voiding: $9.69 \pm 2.47$ vs $8.14 \pm 3.21,(\mathrm{p}=0.039)$ and post micturition: $3.63 \pm$ 1.26 vs $2.69 \pm 1.744,(p=0.045)$ symptoms significantly. Among the voiding symptoms, urgency score was higher in DM patients: $2.88 \pm 1.26$ vs $1.81 \pm 1.77(\mathrm{p}=0.08)$.

Table 2 Differences in IPSS questionnaire results between patients with and without DM group

\begin{tabular}{lccl}
\hline \multicolumn{1}{c}{ Variables } & DM & Non-DM & P value \\
\hline Number of patients & 16 & 81 & \\
IPSS score & $21.69 \pm 5.41$ & $16.70 \pm 3.72$ & $0.005^{*}$ \\
Storage & $8.38 \pm 4.573$ & $5.88 \pm 3.72$ & $0.020^{*}$ \\
Q3 & $2.88 \pm 1.59$ & $2.04 \pm 1.64$ & 0.063 \\
Q5 & $3.00 \pm 1.71$ & $2.16 \pm 1.61$ & 0.062 \\
Q6 & $2.50 \pm 1.67$ & $1.68 \pm 1.71$ & 0.081 \\
Voiding & $9.69 \pm 2.47$ & $8.14 \pm 3.21$ & $0.039^{*}$ \\
Q2 & $3.56 \pm 1.41$ & $3.10 \pm 1.38$ & 0.223 \\
Q4 & $2.88 \pm 1.26$ & $1.81 \pm 1.78$ & $0.008^{*}$ \\
Q7 & $3.25 \pm 1.13$ & $3.22 \pm 1.20$ & 0.932 \\
Post micturition or & $3.63 \pm 1.26$ & $2.69 \pm 1.74$ & $0.045^{*}$ \\
Q1 & & & \\
Q1 = incomplete emptying; Q2 = frequency; Q3 = intermittency; Q4 = urgency with or \\
without incontinence; Q5 = weak-steam; Q6 = straining; Q7 = nocturia; *P value $<0,050$
\end{tabular}

\section{Discussion}

BPH is believed to cause LUTS through a dynamic component of increased smooth muscle tone mediated by $\alpha-1$ adrenergic receptors as well as a static component of BOO due to the mass of the prostate.[6] While diabetes could be explained by multiple pathways. First, hyperinsulinemia is associated with increased sympathetic nerve activity. The second, dysregulation of the insulinlike growth factor (IGF). IGF has similarity structure in prostate cells. Insulin combines with to IGF receptor enters prostate cells, causing receptor activation to induce growth and proliferation. Third, insulin may increase the transcription of genes/ translation of proteins involved in sex hormone metabolism influencing the prostatic hormonal milieu.[9-11] 
In this study, DM patients clearly show differences in LUTS symptoms. Similarly, a study by Ozcan et al results in a significantly higher total IPSS score in patients with DM.[12] Bang et al. analyzed an association between DM and increased prostate volume indicating that DM is an important factor for a static component of BPH/LUTS.[13] The total IPSS, storage symptom, and post micturition symptom scores are significantly higher in the DM group. While voiding symptoms did not show significant differences. Among storage symptoms, frequency and nocturia also showed significant differences. On the contrary, we found significant differences in voiding and its urgency symptom. Initial osmotic diuresis induced by hyperglycemia causes bladder wall stretching, along with increased intravesical pressure results in compensated bladder hypertrophy. This would correspond clinically to storage symptoms at first. As the disease progresses, advanced glycation end products induce delirious changes. Oxidative stress releases toxic products that result in bladder decompensation. Hyperinsulinemia is connected to sympathetic nerve activity that causes increasing in prostatic smooth muscle and bladder obstruction.[9-11] The obstruction causes bladder dysfunction-detrusor muscle instabilityclinically related to frequency and urgency. Along with those symptoms, trabeculation as a result of increased detrusor muscle collagen could cause an incomplete emptying sensation.[14]

Limitations to this study were: sample size of the study was not equal, subjective answers might not be consistent with actual bladder dysfunction, and how long a patient had DM.

\section{Conclusions}

Benign Prostatic Hyperplasia patients with DM manifested more severe lower urinary tract symptoms. Storage, voiding, post micturition, and urgency subscore symptoms were also greater but not in the other subscore symptoms.

\section{REFERENCE}

[1] McVary K. T., Roehrborn C. G., Avins A. L., Barry M. J., Bruskewitz R. C., Donnell R. F., Foster H. E., Jr., et al. "Update on AUA Guideline on the Management of Benign Prostatic Hyperplasia," The Journal of Urology, 2011,vol.185,p:1793-803..

[2] Cooperberg M. R., Presti J. C., Shinohara K., \& Carroll P. R., in: McAninch J. W., \& Lue T. F., Neoplasms of the Prostate Gland, Smith and Tanagho's General Urology, 8th ed, San Fransisco, 2013,p:350.

[3] Chughtai, B., Forde, J. C., Thomas, D. D. M., Laor, L., Hossack, T., Woo, H. H., et al. "Benign Prostatic Hyperplasia," Nature Reviews Disease Primers, 2016,vol.2,no.16031,p: $1-15$.

[4] Vignozzi L, Gacci M., \& Maggi M., "Lower Urinary Tract Symptoms, Benign Prostatic Hyperplasia and Metabolic Syndrome," Nature Reviws Urology, 2016,p:1-12.

[5] Vuichoud, C. \& Loughlin, K. R., "Benign Prostatic Hyperplasia: Epidemiology, Economics and Evaluation," Canadian Journal of Urology, 2015,vol.22,no.1,p:1-6.

[6] Ikatan Ahli Urologi Indonesia (IAUI), "Panduan Penatalaksanaan Klinis Pembesaran Prostat Jinak (Benign Prostate Hyperplasia/BPH)," Ikatan Ahli Urologi Indonesia, 2017. ISBN 978602-61866-0-7. [Online]. Available: http://iaui.or.id/. [Accessed: Apr. 17, 2019].

[7] Gomez, C. S., Kanagarajah, P., \& Gousse, A. E., "Bladder Dysfunction in Patients with Diabetes." Current Urology Reports, vol. 12, no. 6, pp. 419-426. 2011. 
[8] Parsons, J. K., "Benign Prostatic Hyperplasia and Male Lower Urinary Tract Symptoms: Epidemiology and Risk Factors," Current Bladder Dysfunction Reports, 2014.vol.5,no.4, p: 212-8.

[9] Sarma, A. V., Parsons, J. K., McVary, K., \& Wei, J. T., "Diabetes and Benign Prostatic Hyperplasia/Lower Urinary Tract Symptoms-What do We Know?," Journal of Urology, 2009,vol.182,no.9,p:32-7.

[10] Ngai H.Y., Yuen K. K. S., Ng C. M., Cheng C. H., \& Chu S. K. P., "Metabolic Syndrome and Benign Prostatic Hyperplasia: An Update," Asian Journal of Urology, 2017. doi: 10.1016/ j.ajur.2017.05.001.

[11] Breyer, B. N. \& Sarma, A. V., "Hyperglycemia and Insulin Resistance and the Risk of BPH/LUTS: an Update of Recent Literature," Current Urology Reports, 2014,vol.15, no.12, $\mathrm{p}: 1-6$.

[12] Ozcan L., Besiroglu H., Dursun M., Polat E. C., Otunctemur A., \& Ozbek E., "Comparison of the Clinical Parameters of Benign Prostate Hyperplasia in Diabetic and non Diabetic Patients," Archivio Italiano di Urologia e Andrologia, 2017, vol.89,no.1,p:26-30.

[13] Bang, W. J., Lee, J. Y., Koo, K. C., Hah, Y. S., Lee, D. H., \& Cho, K. S., "Is Type-2 Diabetes Mellitus Associated With Overactive Bladder Symptoms in Men With Lower Urinary Tract Symptoms," Urology, 2014,vol.84,no.3,p:670-4.

[14] Roehrborn \& Claus G., in: Partin A., Peters C., Kavoussi L., Dmochowski R., \& Wein A., Benign Prostatic Hyperplasia: Etiology, Pathophysiology, Epidemiology, and Natural History, Campbell-Walsh Urology, Philadelphia, 2016,p.2435. 